\title{
PRZYWIĄZANIE A SATYSFAKCJA MAŁŻEŃSKA WSPÓŁMAŁŻONKÓW OSÓB Z NIEPELNOSPRAWNOŚCIĄ RUCHOWĄ
}

$W$ artykule zaprezentowano wyniki badań własnych poświęconych zwiazkom stylów przywiązania z malżeńską satysfakcja u partnerów osób z niepetnosprawnościq ruchowq. Analizy zmierzaly do ustalenia, jakie jest nasilenie stylów przywiąania (bezpiecznego, unikowego oraz lękowo-ambiwalentnego) oraz określenia poziomu satysfakcji ze zwiąku w jej wymiarze ogólnym i szczególowych (intymności, rozczarowania, samorealizacji i podobieństwa), ponadto relacji między obiema zmiennymi. Dokonano również weryfikacji znaczenia dla analizowanej relacji zmiennych, takich jak przyczyna niepetnosprawności matżonka oraz percepcja niepetnosprawności przez petnosprawnego matzonka. Materiat badawczy uzyskano od 85 malżonków osób niepetnosprawnych na skutek urazu rdzenia, stwardnienia rozsianego, udaru mózgu i amputacji kończyny dolnej. W badaniach Zastosowano Kwestionariusz Dobranego Matżeństwa (KDM-2) w opracowaniu M. Plopy i J. Rostowskiego; Kwestionariusz Stylów Przywiazaniowych (KSP) M. Plopy; Kwestionariusz Oceny Trwałej Niepelnosprawności/Choroby Przewlektej i Ograniczeń Towarzyszacych S. Byry oraz kwestionariusz własnej konstrukcji.

Stowa kluczowe: style przywiązania, satysfakcja matżeńska, malżeństwo, niepetnosprawność ruchowa.

* Dr hab. Stanisława Byra - adiunkt, Instytut Pedagogiki, Wydział Pedagogiki i Psychologii UMCS w Lublinie.

** Dr hab. Monika Parchomiuk - adiunkt, Instytut Pedagogiki, Wydział Pedagogiki i Psychologii UMCS w Lublinie. 
Przywiązanie oznacza określony stopień zaufania i bezpieczeństwa w związkach interpersonalnych, kształtujący się w bardzo wczesnej fazie rozwoju człowieka w relacjach z osobami znaczącymi, przede wszystkim matką ${ }^{1}$. Twórcą koncepcji wyjaśniającej mechanizmy tworzenia przywiązania, jego działania oraz korelaty jest J. Bowlby². Dorobek badacza był rozwijany m.in. przez M. Ainsworth, która wskazała trzy style przywiązania (bezpieczny, lękowo-ambiwalentny, unikający), charakteryzujące różny stopień realizacji potrzeby bezpieczeństwa oraz specyficzne jego konsekwencje w emocjonalno-uczuciowym i behawioralnym aspekcie ${ }^{3}$. Rozwój przywiązania obejmuje przede wszystkim krystalizowanie wewnętrznych modeli operacyjnych, zawierających model postaci przywiązania, model Ja oraz model relacji między innymi a Ja w zakresie przywiązania ${ }^{4}$. Dostępność osób znaczących połączona $\mathrm{z}$ wrażliwością na potrzeby dziecka (związana m. in. ze zdolnością rozpoznawania jego emocji i reagowania na nie w sposób adekwatny) decyduje o rozwijaniu u niego pozytywnych przekonań na temat modelu przywiązania. Dzięki generalizacji takie przekonania mogą tworzyć się w odniesieniu do innych ludzi oraz samego siebie. Powstaje model Ja zawierający przekonania na temat siebie jako osoby godnej miłości i akceptacji. Efektywna z perspektywy dziecka odpowiedź opiekuna na sygnały emocjonalne wzmacnia dążenie do kontaktów z nim, przywraca poczucie bezpieczeństwa i decyduje o budowaniu bezpiecznego stylu przywiązania, dla którego specyficzna jest otwartość i plastyczność ekspresji emocjonalnej. Mała dostępność potencjalnych modeli przywiązania wraz z niedostateczną ich gotowością do działań pomocowych i opiekuńczych wobec dziecka, staje się przyczyną rozwijania u niego negatywnych przekonań na temat innych i samego siebie. Rozwija się strategia deaktywacji, polegająca na tłumieniu reakcji afektywnych i behawioralnych wobec osoby znaczącej i innych (przy stylu unikowym) oraz strategia heperaktywacji, dla której specyficzne jest wyolbrzymianie zachowań przywiązaniowych i emocji (przy stylu ambiwalentnym) ${ }^{5}$.

1 H. Liberska, D. Suwalska, Styl przywiązania a relacje partnerskie we wczesnej dorosłości, „Psychologia Rozwojowa” 2011, t. 16 (1), s. 26.

2 J. Bowlby, Przywiazanie, Warszawa 2007.

3 M. Plopa, Więzi w matżeństwie i rodzinie. Metody badań, Kraków 2007, s. 270.

4 J. Bowlby, za P. Marchwicki, Style przywiazania a postawy rodzicielskie. Doniesienie z badań, „Roczniki Psychologiczne” 2004, t. VII (2), s. 83.

5 M. Plopa, Więzi w matżeństwie....d. dz. cyt., s. 271. 


\section{Znaczenie stylu przywiązania w relacjach partnerskich}

Ukształtowany w dzieciństwie styl uważa się za swoisty prototyp relacji społecznych realizowanych na późniejszych etapach życia. Traktowany w kategoriach wewnętrznego aktywnego modelu, po części poddającego się modyfikacjom pod wpływem kolejnych doświadczeń, obejmuje m.in. zdolność samoregulacji emocjonalno-uczuciowej i emocjonalną ekspresję w związkach ${ }^{6}$. Teoria przywiązania stała się podstawą badań nad relacjami intymnymi dorosłych. C. Hazan i P. Shaver ${ }^{7}$ stwierdzili, że miłość może być konceptualizowana jako połączenie elementów przywiązania, opieki oraz seksualnego doboru. Relacje przywiązaniowe dorosłych mają swoją specyfikę. Wyraża się ona w swoistej wzajemności, polegającej na tym, że partnerzy są jednocześnie dawcami i odbiorcami opieki. Obecność fizyczna partnera, dzięki internalizacji przekonań i oczekiwań, nie musi być czynnikiem niezbędnym dla poczucia bezpieczeństwa (związanego z realizacją potrzeb). Kształtowanie relacji z perspektywy przywiązania dokonuje się w kontekście fizycznej bliskości, w przypadku związku intymnego czynnikiem prowokującym jest system seksualnego doboru (seksualnej atrakcyjności). Badania pokazały jednak, że wzajemna atrakcyjność oraz seksualne zainteresowanie są najbardziej znaczące we wczesnej fazie relacji, z czasem wzrasta znaczenie doświadczania dobrostanu i emocjonalnego wsparcia ${ }^{8}$.

C. Hazan i P. Shaver ${ }^{9}$ na podstawie badań własnych dokonali charakterystyki trzech stylów przywiązania w kontekście funkcjonowania intymnego związku. Bezpieczne przywiązanie charakteryzuje się odczuwaniem zadowolenia z bliskich relacji, wzajemnej zależności, akceptowaniem zachowań partnera ukierunkowanych na zacieśnianie więzi. Opiera się na przekonaniu o wsparciu partnera w zmaganiu się z sytuacjami trudnymi, w podejmowaniu ważnych, przełomowych decyzji. Cechuje się zaufaniem, otwartością, okazywaniem czułości, przywiązania, satysfakcjonującą komunikacją i radością z bycia razem. Związki tworzone przez osoby cechujące się tym stylem były dłuższe i trwalsze od pozostałych. Styl unikowy cechuje się dyskomfortem w bliskości, trudnościami w otwartości, pełnym zaufaniu, osłabioną skłonnością do budowania autentycznych więzi i spontaniczności w codziennym funkcjonowaniu. Unikanie określane jest również

\footnotetext{
6 Tamże, s. 272.

7 C. Hazan, P. Shaver, Attachment as an organizational framework for research on close relationships, „Psychological Inquiry” 1994, t. 5 (1), s. 8.

8 C. Hazan, P. Shaver, Attachment..., dz. cyt., s. 11.

9 C. Hazan, P. Shaver, Romantic love conceptualized as an attachment process, „Journal of Personality and Social Psychology” 1987, t. 52 (3), s. 514 i n.
} 
przez zażenowanie, irytację, opór w sytuacjach zmierzania partnera do bliskości, większej intymności i opiera się na wyraźnie zaznaczonych granicach między partnerami ${ }^{10}$. Styl lękowo-ambiwalentny określa przeświadczenie o braku gotowości partnera do wchodzenia w bliskie oczekiwane relacje, niepewność co do jego rzeczywistych uczuć oraz niepokój o trwałość związku. Składa się na niego lęk przed utratą partnera generujący nadmierną czujność, podejrzliwość, zdenerwowanie, wyczulenie na punkcie postrzegania atrakcyjności relacji przez partnera. Miłość osób o stylu lękowo-ambiwalentnym ma charakter obsesyjny, towarzyszy im pragnienie wzajemności i jedności, doświadczają nagłego nasilenia i spadku emocji, ekstremalnej seksualnej atrakcyjności i zazdrości.

Te swego rodzaju pionierskie tendencje zostały potwierdzone w wielu kolejnych eksploracjach, polskich i zagranicznych. Zidentyfikowano emocjonalno-uczuciowe oraz behawioralne wzorce specyficzne dla funkcjonowania w związkach osób o różnych stylach przywiązania, zaznaczające się w obszarze satysfakcji ze związku, stylach miłości, wsparciu i opiece, zachowaniach seksualnych, strategiach komunikacji i rozwiązywania konfliktów, ponadto przemocy ${ }^{11}$. Wskazuje się na dwa mechanizmy leżące u podstaw wskazanych powiązań. Jednym z nich jest wpływ stylu przywiązania na społeczną percepcję, emocjonalno-uczuciowe wzorce reakcji oraz zachowania interpersonalne ${ }^{12}$. Jak wcześniej pisano, wewnętrzne modele operacyjne ukształtowane w ramach stylu przywiązania decydują o sposobach myślenia, odczuwania i zachowania się w sposób, który sprzyja bądź utrudnia nawiązywanie relacji społecznych oraz ich utrzymywanie na satysfakcjonującym poziomie. Określony styl przywiązania decyduje o charakterze postrzegania partnera w kontekście jego funkcjonowania w związku. Można sądzić przykładowo,

M. Plopa, Więzi w matżeństwie..., dz. cyt., s. 275 i 287-288.

11 R. R. Kobak, C. Hazan, Attachment in marriage: effects of security and accuracy of working models, „Journal of Personality and Social Psychology” 1991, t. 60 (6), s. 862 i n.; J. A. Feeney, Attachment, marital interaction, and relationship satisfaction: A diary study, „Personal Relationships” 2002, t. 9, s. 40 i n.; W. S. Rogers, J. Bidwell, L. Wilson, Perception of and satisfaction with relationship power, sex, and attachment styles: a couples level analysis, „Journal of Family Violence” 2005, t. 20 (4), s. 248; O. Özmen, G. Atik, Attachment styles and marital adjustment of Turkish married individuals, „Procedia Social and Behavioral Sciences" 2010, t. 5, s. 370; F. A. Ottu, U. I. Akpan, Predicting marital satisfaction from the attachment styles and gender of a culturally and religiously homogenous population, „Gender and Behaviour” 2011, t. 9(1), s. 3669; M. Kaźmierczak, M. Błażek, Attachment styles as predictors of the perception of couples' cohesion, „Social Behavior and Personality" 2015, t. 43 (6), s. 1056.

12 K. Palus, Wybrane psychologiczne uwarunkowania braku partnera życiowego w okresie wczesnej dorosłości, Poznań 2010, s. 38. 
że osoby o stylu bezpiecznym częściej oceniają zachowania swoich partnerów jako konstruktywne dla relacji oraz podyktowane dobrymi intencjami, nawet jeśli $\mathrm{z}$ obiektywnego punktu widzenia nie mogą być postrzegane jako takie ${ }^{13}$. Ponadto wykazano, że style przywiązania różnicują znaczenie zachowania małżonka dla satysfakcji ze związku - osoby o lękowym stylu wykazują silniejszą wrażliwość na negatywne jego efekty ${ }^{14}$.

Drugi mechanizm wyjaśniający zakłada, że styl przywiązania decyduje o wyborze partnera o określonym typie osobowości czy stylu przywiązania, reprezentujących właściwości o pozytywnym czy negatywnym znaczeniu dla jakości związku (np. osoby o stylu unikowym mogą wchodzić w związki z partnerami nieudzielającymi wsparcia) ${ }^{15}$. Większość badań pokazuje tendencję dopasowywania osób w zakresie cech przywiązaniowych, możliwe są jednak sytuacje, kiedy style partnerów są niespójne ${ }^{16}$. Wyniki eksploracji dowodzą, że działanie indywidualnych stylów przywiązania, zaznaczające się w subiektywnie ocenianej jakości związku, ma charakter komplementarny. Satysfakcję wyjaśnia styl przywiązania każdego z małżonków oraz ich kombinacja, w zakresie której obserwuje się efekty o charakterze kompensacyjnym ${ }^{17}$. D. A. Cohn i współautorzy ${ }^{18}$ wykazali, że pary stworzone z osoby o bezpiecznym i lękowym stylu przywiązania funkcjonują w pewnych zakresach (poziom konfliktu i zachowań pozytywnych) podobnie do związków tworzonych przez dwie jednostki o stylach bezpiecznych. Sugeruje się, że osoba „bezpieczna” może buforować negatywne efekty lękowego przywiązania partnera. $Z$ drugiej strony można mówić o relacji zwrotnej między stylami przywiązania a funkcjonowaniem partnerów w związku ${ }^{19}$. Style wpływają na zachowania i przystosowanie w związku, ale same podlegają ich działaniu. Analizując powiązania stylów z charakterem relacji (w tym satysfakcją) należy wspomnieć o udowodnionej empirycznie roli czynników pośredniczących, takich jak emocjonalna ekspresyjność, strategie radzenia sobie z konfliktami, wsparcie

\footnotetext{
3 J. A. Feeney, Attachment..., dz. cyt., s. 41.

14 Tamże.

15 K. Palus, Wybrane psychologiczne..., dz. cyt., s. 38.

16 J. A. Feeney, Attachment..., dz. cyt., s. 41.

17 R. Banse, Adult attachment and marital satisfaction: Evidence for dyadic configu-
} ration effects, „Journal of Social and Personal Relationships” 2004, t. 21 (2), s. 280; A. M. Jarnecke, S. C. South, Attachment orientations as mediators in the intergenerational transmission of marital satisfaction, ,Journal of Family Psychology”2013, t. 27 (4), s. 556.

18 Za J. A. Feeney, Attachment..., dz. cyt., s. 41

19 R. R. Kobak, C. Hazan, Attachment in marriage..., dz. cyt., s. 867; N. L. Collins, S. J. Read, za J. A. Feeney, Attachment..., dz. cyt., s. 41. 
społeczne otrzymywane poza związkiem, ocena spójności związku, stadium jego rozwoju czy płeć partnera ${ }^{20}$. Wykazano między innymi, że bezpieczne style przywiązania działają jako swoiste zasoby, powiązane $\mathrm{z}$ efektywniejszym radzeniem sobie, mniejszym nasileniem psychologicznych objawów stresu oraz silniejszym poczuciem dobrostanu ${ }^{21}$. Jak wcześniej pisano, poprzez specyficzne wewnętrzne modele operacyjne, optymalizują społeczne funkcjonowanie jednostki, w tym zdolność pozyskiwania i wykorzystywania wsparcia. Zarówno wsparcie, jak i poczucie dobrostanu są pozytywnie powiązane z małżeńską satysfakcją ${ }^{22}$.

\section{Związki partnerów niepełno- i pelnosprawnych}

Przedmiotem badań własnych są korelacje stylów przywiązania z małżeńską satysfakcją osób mających za partnera osobę z niepełnosprawnością ruchową. Znaczne zasoby badań z udziałem przedstawicieli tej populacji pozwalają dokonać jej charakterystyki z perspektywy swoistego przystosowania do życia z partnerem niepełnosprawnym, z uwzględnieniem możliwych trudności, zdolności radzenia sobie oraz satysfakcji. C. Hazan i P. Shaver ${ }^{23}$ piszą, że satysfakcja ze związku w największym zakresie zależy od zaspokojenia podstawowych potrzeb - dobrostanu, opieki oraz potrzeby seksualnej. Badania informują o możliwych zakłóceniach $w$ ich realizacji u jednostki pełnosprawnej mającej za partnera osobę niepełnosprawną fizycznie ${ }^{24}$. Należy jednak zauważyć, że istnieją różnice

20 L. A. Kirkpatrick, K. E. Davis, Attachment style, gender, and relationship stability: a longitudinal analysis, „Journal of Personality and Social Psychology” 1994, t. 66 (3), s. 509; B. Paley, M. J. Cox, M. R. Burchinal, C. C. Payne, Attachment and marital functioning: comparison of spouses with continuous-secure, earned-secure, dismissing, and preoccupied attachment stances, ,Journal of Family Psychology” 1999, t. 13 (4), s. 591; J. A. Feeney, Attachment..., dz. cyt., s. 41; M. Kaźmierczak, M. Błażek, Attachment styles..., dz. cyt., s. 1056.

${ }_{21}$ S. A. Meyers, S. A. Landsberger, Direct and indirect pathways between adult attachment style and marital satisfaction, „Personal Relationships” 2002, t. 9, s. 160 i n.

22 S. A. Meyers, S. A. Landsberger, Direct and indirect..., dz. cyt., s. 167.

23 C. Hazan, P. Shaver, Attachment..., dz. cyt., s. 13...

24 J. F. Ybema, R. G. Kuijer, M. Hagedoorn, B. P. Buunk, Caregiver burnout among intimate partners of patients with a severe illness: An equity perspective, „Personal Relationships" 2002, t. 9 (1), s. 79-81. L. Blane, M. I. Carmagnani, L. M. Ferreira, Healthrelated quality of life of primary caregivers of persons with paraplegia, „Spinal Cord” 2007, t. 45 (6), s. 401; Ch. J. McPherson, K. G. Wilson, L. Chyurlia, Ch. Leclerc, The caregiving relationship and quality of life among partners of stroke survivors: A cross-sectional study, „Health and Quality of Life Outcomes” 2011,t. 9, s. 29. D. A. Weitzenkamp, K. A. Gerhart, 
indywidualne związane $\mathrm{z}$ wieloma czynnikami, w tym między innymi charakteryzującymi samą niepełnosprawność, środowisko funkcjonowania związku i jego specyfikę (m.in. staż, czas nabycia niepełnosprawności), ponadto cechami osobowościowymi parterów. W efekcie określone w drodze eksploracji tendencje opisujące wskaźniki jakości relacji są zróżnicowane. Niektóre badania informują o wyższej stabilności i spójności związków, porównywalnej do małżeństw pełnosprawnych osób satysfakcji globalnej, wzroście satysfakcji na przestrzeni czasu, ale także charakterystycznym nasileniu specyficznych problemów (np. seksualnych, komunikacyjnych ${ }^{25}$. Inne z kolei wskazują na brak satysfakcji ze związku lub niższy jego poziom niż w grupie porównawczej, zwłaszcza u małżonków pełnosprawnych $^{26}$.

Nie znaleziono badań poświęconych problematyce stylów przywiązania realizowanych z udziałem partnerów osób niepełnosprawnych. Eksploracje obejmujące relacje stylów przywiązaniowych z satysfakcją małżeńską prowadzono między innymi w grupie małżonków chorych na raka ${ }^{27}$. Uzyskane wyniki potwierdziły dotychczasowe tendencje. Pokazały również znaczenie nie tylko osobistego stylu przywiązania małżonka dla jego satysfakcji, ale również stylu partnera.

S. W. Charlifue, G. G. Whiteneck, G. Savic, Spouses of spinal cord injury survivors: the added impact of caregiving, „Archives of Physical Medicine and Rehabilitation” 1997, t. $78(8)$, s. 824.

25 T. M. Jaworski, J. S. Richards, L. K. Lloyd, Retrospective review of sexual and marital satisfaction of spinal cord of spinal cord injury and diabetic males post penile injection or implant, „Urology” 1992, t. 40 (2), s. 127-131; S. Y. Yim, I. Y. Lee, S. H. Yoon, M. S. Song, E. W. Rah, H.W. Moon, Quality of marital life in Korean spinal cord injured patients, ,Spinal Cord" 1998, t. 36, s. 828-829; B. L. Bermas, J. S. Tucker, D. K. Winkelman, J. N. Katz, Marital satisfaction in couples with rheumatoid arthritis, „Arthritis Care Research” 2000, Vo. 13 (3), s. 150-155; M. J. Redeleman, Sexual difficulties for persons with multiple sclerosis in New South Wales, Australia, „International Journal of Rehabilitation Research” 2009, t. 32 (4), s. 337-347; E. J. O'Connor, M. P. McCabe, Predictors of quality of life in carers for people with a progressive neurological illness: a longitudinal study, ,Quality Life Research" 2011, t. 20, s. 707.

26 W. van Lankveld, G. Ruiterkamp, G. Näring, D. J. de Rooij, Marital and sexual satisfaction in patients with RA and their spouses. „Scandinavian Journal of Rheumatology” 2004, t. 33, s. 406; E. J. O'Connor, M. P. McCabe, L. Firth, The impact of neurological illness on marital relationships, „Journal of Sex and Marriage Therapy” 2008, t. 24, s. 128.

27 C. G. Shields, L. A.Travis, S. L. Rousseau, Marital attachment and adjustment in older couples coping with cancer, ,Aging and Mental Health” 2000, t. 4 (3), s. 230. 


\section{Założenia badań własnych}

Głównym celem badań własnych było określenie związku między stylami przywiązania a satysfakcją małżeńską współmałżonków osób z niepełnosprawnością ruchową. Skoncentrowano się na ustaleniu udziału stylów przywiązania w wyjaśnianiu zmienności wskaźników satysfakcji małżeńskiej. Sformułowano również szczegółowe problemy badawcze:

1. Jaki jest poziom satysfakcji małżeńskiej u współmałżonków osób z niepełnosprawnością ruchową, ogólnie rozumianej oraz w wymiarach: intymności, samorealizacji, podobieństwa oraz rozczarowania?

2. Jakie style przywiązaniowe są charakterystyczne dla badanych współmałżonków osób z niepełnosprawnością ruchową?

3. Czy istnieje związek między stylami przywiązania a satysfakcją małżeńską u współmałżonków osób z niepełnosprawnością ruchową? A jeżeli tak, to jaki ma on charakter?

4. Czy przyczyna niepełnosprawności małżonka oraz percepcja niepełnosprawności przez pełnosprawnego małżonka ma znaczenie dla siły i charakteru powiązania między uwzględnionymi zmiennymi?

Wysunięto dwie hipotezy. Po pierwsze, przyjęto na podstawie dotychczasowych ustaleń $^{28}$, że istnieje istotny związek między stylami przywiązaniowymi a satysfakcją małżeńską u współmałżonków osób z niepełnosprawnością ruchową. Przypuszcza się przy tym, iż negatywne formy przywiązania dodatnio korelują z negatywnym wskaźnikiem zadowolenia małżeńskiego, natomiast przywiązanie o charakterze pozytywnym dodatnio wiąże się z pozytywnymi wymiarami satysfakcji małżeńskiej. Druga hipoteza odnosi się do istotnego udziału zmiennych związanych z niepełnosprawnością: przyczyny niepełnosprawności i jej percepcji przez pełnosprawnego małżonka w ustalaniu charakteru powiązania między stylami przywiązaniowymi a satysfakcją małżeńską wśród małżonków osób z niepełnosprawnością ruchową ${ }^{29}$.

Satysfakcja małżeńska definiowana jest za pomocą następujących wymiarów: intymności, rozczarowania, samorealizacji i podobieństwa odnoszących się do

28 J. Rostowski, T. Rostowska, Małżeństwo i miłość. Kontekst psychologiczny i neuropsychologiczny, Warszawa 2014, s. 98; M. Plopa, Więzi w matzeństwie... dz. cyt., s. 299.

29 A. Dickson, G. O'Brien, R. Ward, D. Allan, R. O'Carroll, The impact of assuming the primary caregiver role following traumatic spinal cord injury: An interpretative phenomenological analysis of the spouse's experience, „Psychology and Health” 2010, t. 25(10), s. 1116; M. Chandler, P. Kennedy, N. Sandhu, The association between threat appraisals and psychological adjustment in partners of people with spinal cord injuries, ,Rehabilitation Psychology" 2007, t. 52(4), s. 474-475. 
różnych obszarów relacji, nakreślających rozbudowany jej obraz. Obejmuje zadowolenie $\mathrm{z}$ bycia $\mathrm{w}$ bliskiej relacji, wzajemnego zaufania i uszczęśliwiania się; możliwości realizacji własnych zamierzeń, preferowanych wartości w kontekście wspólnego życia; zgodności w dążeniach i osiąganiu wartościowych celów małżeńskich i rodzinnych, spędzaniu wolnego czasu, definiowaniu przyszłości. Istotnym wskaźnikiem jakości związku małżeńskiego jest również stopień rozczarowania dotyczący głównie poczucia blokady w zaspokajaniu potrzeby autonomii i życia zgodnie z przyjmowanymi zasadami i wyobrażeniami ${ }^{30}$.

Style przywiązaniowe, $\mathrm{tj}$. bezpieczny, lękowo-ambiwalentny i unikowy oraz potencjalne ich znaczenie dla relacji partnerskich osób badanych i odczuwanej przez nich satysfakcji, rozumiane są zgodnie z opisaną wcześniej koncepcją C. Hazan i P. R. Shavera. W wyjaśnianiu ich znaczenia dla przyjęto założenia formułowane przez autorów koncepcji ${ }^{31}$.

W kategorii przyczyna niepełnosprawności współmałżonka uwzględniono: uraz rdzenia kręgowego, stwardnienie rozsiane oraz udar mózgu. $Z$ racji dowiedzionego znaczenia nie tylko obiektywnych parametrów niepełnosprawności dla psychospołecznego funkcjonowania osób jej doświadczających i ich partnerów, ale także subiektywnej percepcji doznawanych ograniczen ${ }^{32}$, określona została perspektywa postrzegania niepełnosprawności przez pełnosprawnego małżonka. Postrzeganie niepełnosprawności ujęto w trzech kategoriach: straty, zagrożenia i wyzwania. Traktowanie niepełnosprawności współmałżonka w formie straty wiąże się z wartościowaniem obecnego wspólnego funkcjonowania w kontekście doświadczanych ograniczeń, przy odwoływaniu się do przeszłości i dysponowanych wówczas możliwości. Ocena niepełnosprawności jako zagrożenia wyraża koncentrację na trudnościach, przeszkodach generowanych przez niepełnosprawność współmałżonka w osiąganiu ważnych celów życiowych. Z kolei postrzeganie niepełnosprawności w kategorii wyzwania opiera się na przekonaniu, iż ograniczenia współmałżonka nie uniemożliwiają realizacji wartościowych planów i zamierzenn ${ }^{33}$.

30 M. Plopa, Więzi w matżeństwie..., dz. cyt., s. 69-70.

31 Za: tamże, s. 276; 275 i 287-288.

32 K. Ackroyd, D. G. Fortune, S. Price, S. Howell, B. Sharrack, C. L. Isaac, Adversarial growth in patients with multiple sclerosis and their partners: relationships with illness perceptions, disability and distress, „Journal of Clinical Psychology in Medical Settings” 2011, t. 18, s. 376.

33 Por. S. Byra, Przystosowanie do życia z niepetnosprawnościa ruchowa i choroba przewlekta. Struktura i uwarunkowania, Lublin 2012, s. 108-109; I. Heszen-Niejodek, Problemy chorych somatycznie, w: Psychologia. Podręcznik akademicki, red. J. Strelau, t. 3, Gdańsk 2005, s. 514. 
W badaniach wzięło udział 85 współmałżonków osób z niepełnosprawnością ruchową, wśród których dominowali mężczyźni (70,79\%). Średnia wieku badanych wynosi 47,82 ( $\mathrm{SD}=8,58)$. W największym odsetku zamieszkują większe miasta: wojewódzkie - (37,65\%), powiatowe - (35,29\%). Mieszkańcami małych miast jest $18,82 \%$ badanych, a $8,23 \%$ osób mieszka na wsi. Struktura wykształcenia badanych jest zróżnicowana: wykształcenie wyższe (35,29\%), średnie ogólne $(25,88 \%)$, średnie zawodowe $(15,29 \%)$, zasadnicze zawodowe $(12,94 \%)$, podstawowe $(4,70 \%)$, policealne/pomaturalne (3,53\%), niepełne wyższe (2,35\%). Zdecydowana większość respondentów wychowuje dzieci $(77,65 \%)$, ich liczba mieści się w przedziale od 1 do 5. Materialna sytuacja rodziny oceniana jest przez badanych najczęściej jako przeciętna $(43,53 \%)$ lub dobra $(41,18 \%)$, niewielki ich odsetek ocenił jako bardzo dobrą $(9,41 \%)$ bądź złą (5,88\%).

Niepełnosprawność małżonków osób badanych jest konsekwencją głównie urazu rdzenia kręgowego (40\%) i stwardnienia rozsianego (36,47\%). Przyczyny niepełnosprawności pozostałych współmałżonków to udar mózgu (20\%) i amputacja kończyny dolnej (3 osoby). Najwięcej badanych postrzega niepełnosprawność współmałżonka w kategorii wyzwania (42,35\%), jako strata traktowana jest przez $24,71 \%$ respondentów, a w formie zagrożenia ujmowana jest przez 22,35\% ankietowanych.

Materiał badawczy zebrano za pomocą następujących narzędzi: Kwestionariusz Dobranego Małżeństwa (KDM-2) w opracowaniu M. Plopy i J. Rostowskiego; Kwestionariusz Stylów Przywiązaniowych (KSP) M. Plopy; Kwestionariusz Oceny Trwałej Niepełnosprawności/Choroby Przewlekłej i Ograniczeń Towarzyszących S. Byry oraz kwestionariusz własnej konstrukcji obejmujący socjodemograficzną charakterystykę osoby badanej i jej współmałżonka doświadczającego niepełnosprawności ruchowej.

KDM-2 służy do pomiaru satysfakcji małżeńskiej z perspektywy czterech wymiarów: intymności, rozczarowania, samorealizacji i podobieństwa oraz wyniku ogólnego. Narzędzie posiada satysfakcjonujące wskaźniki psychometryczne. Alfa Cronbacha dla poszczególnych podskal mieści się w przedziale od 0,81-0,8934. KSP umożliwia pomiar trzech stylów przywiązaniowych: bezpiecznego, lękowo-ambiwalentnego i unikowego. Psychometryczne własności kwestionariusza są zadowalające. Alfa Cronbacha dla wyodrębnionych stylów sytuuje się w przedziale od 0,78 do $0,91^{35}$. Kwestionariusz Oceny Trwałej Niepełnosprawności/Choroby Przewlekłej i Ograniczeń Towarzyszących S. Byry umożliwia ustalenie sposobu postrzegania niepełnosprawności w kategorii straty, zagrożenia lub wyzwania ${ }^{36}$.

\footnotetext{
4 M. Plopa, Więzi w matżeństwie..., dz. cyt., s. 72.

5 Tamże, s. 289.

36 S. Byra, Przystosowanie do życia..., dz. cyt., s. 232-233.
} 


\section{Wyniki badań własnych}

Wyniki uzyskane w zakresie satysfakcji małżeńskiej wskazują na niezbyt korzystny obraz relacji osób badanych z ich małżonkami niepełnosprawnymi ruchowo. Dowodzi tego najwyższe natężenie doświadczeń małżeńskich składających się na rozczarowanie, przy jednocześnie niższym nasileniu wszystkich pozytywnych wymiarów ocenianej jakości związku małżeńskiego (tab. 1). Zdecydowana przewaga wyników wysokich w podskali Rozczarowanie ujawnia deklarowane przez badanych poczucie niepowodzenia życiowego, trudności doznawane w utrzymywaniu związku niespełniającego oczekiwania, wskazuje na wyraźnie odczuwany brak przyjemności w byciu razem i raczej tendencje unikowe niż troskę o wspólne rozwiązywanie bieżących problemów. Widoczna jest u nich osłabiona potrzeba budowania satysfakcjonującej relacji opartej na wzajemnym zaufaniu, bliskości, otwartości, obopólnym wspieraniu się. Dostrzegają niewielkie podobieństwo między sobą w zakresie ustanawiania i realizowania celów małżeńskich i rodzinnych, wyznaczania płaszczyzn własnego rozwoju i dbania o wartościowe obszary bycia razem.

Tabela 1. Satysfakcja małżeńska u współmałżonków osób z niepełnosprawnością

\begin{tabular}{lccccccr}
\hline $\begin{array}{l}\text { Wskaźniki } \\
\text { satysfakcji }\end{array}$ & \multirow{2}{*}{ M } & \multirow{3}{*}{ SD } & \multirow{2}{*}{ MIN MAX } & \multicolumn{3}{c}{ Poziom wyników } \\
\hline Intymność & 27,69 & 5,21 & 8 & 40 & $49(57,65 \%)$ & $28(32,94 \%)$ & $8(9,41 \%)$ \\
Rozczarowanie & 31,88 & 7,04 & 10 & 46 & $4(4,71 \%)$ & $10(11,76 \%)$ & $71(83,53 \%)$ \\
Samorealizacja & 24,56 & 3,66 & 8 & 35 & $58(68,23 \%)$ & $24(28,23 \%)$ & $3(3,53 \%)$ \\
Podobieństwo & 24,67 & 4,46 & 7 & 35 & $48(56,47 \%)$ & $25(29,41 \%)$ & $12(14,11 \%)$ \\
Wynik ogólny & 108,67 & 10,58 & 69 & 133 & $74(87,06 \%)$ & $9(10,59 \%)$ & $2(2,35 \%)$ \\
\hline
\end{tabular}

M(średnia); SD (odchylenie standardowe); MIN (minimum); MAX (maksimum); wyniki przeliczone na steny $(\mathrm{N}, \%)$

W kontekście prezentowanego poziomu poszczególnych wymiarów satysfakcji małżeńskiej współmałżonków osób z niepełnosprawnością ruchową interesujące się rezultaty otrzymane w ramach stylów przywiązaniowych (tab. 2). 
Tabela 2. Style przywiązaniowe u współmałżonków osób z niepełnosprawnością

\begin{tabular}{lllllllll}
\hline $\begin{array}{l}\text { Style przywią- } \\
\text { zaniowe }\end{array}$ & \multirow{2}{*}{ M } & \multirow{2}{*}{ SD } & \multirow{2}{*}{ MIN MAX } & \multirow{2}{*}{ Niski } & \multicolumn{3}{c}{ Poziom wyników } \\
\hline Bezpieczny & 35,56 & 11,85 & 15 & 56 & $34(40,00 \%)$ & $7(8,23 \%)$ & $44(51,76 \%)$ \\
\hline $\begin{array}{l}\text { Lękowo- } \\
\text { ambiwalentny }\end{array}$ & 31,12 & 10,44 & 9 & 56 & $16(18,23 \%)$ & $18(21,17 \%)$ & $51(60,00 \%)$ \\
Unikowy & 32,15 & 12,17 & 8 & 56 & $29(34,12 \%)$ & $9(10,59 \%)$ & $47(55,29 \%)$ \\
\hline
\end{tabular}

M(średnia); SD (odchylenie standardowe); MIN (minimum); MAX (maksimum); wyniki przeliczone na steny $(\mathrm{N}, \%)$

Nie zaznaczyła się wśród badanych wyraźna tendencja do określonego stylu charakteryzującego ich przywiązanie do małżonka. W zbliżonym stopniu ujawnia się u nich poczucie bezpieczeństwa, ale również lęku, pewnej ambiwalencji i wycofywania się z relacji. Wyniki te wskazują na złożoną strukturę przywiązania u małżonków pozostających w związku małżeńskim z osobą niepełnosprawną ruchowo. Szczególną uwagę zwracają wyniki w stylu bezpiecznym i znaczący procent zarówno rezultatów wysokich, jak i niskich. Sugeruje to, iż badani nie są w stanie jednoznacznie określić samej natury tego typu przywiązania. Prawdopodobne jest, iż w niektórych sytuacjach, aspektach życia małżeńskiego dostrzegają nasilone bezpieczne przywiązanie, nie występujące lub znacząco obniżone w innych obszarach. Złożoność funkcjonowania małżeńskiego i rodzinnego związanego z obecnością niepełnosprawności małżonka (w tym dynamiką pewnych ograniczeń, np. w przypadku SM), zapewne tworzy odpowiednie podłoże do ujawnianych tutaj trudności w określaniu zakresu bezpiecznego przywiązania. Największy odsetek wyników wysokich w stylu lękowo-ambiwalentnym niejako doprecyzowuje zjawisko przywiązania wśród współmałżonków osób z niepełnosprawnością ruchową. Wskazuje na występujące wśród badanych obawy o trwałość związku (czego źródłem może być choroba prowadząca do znaczącej niepełnosprawności czy też nasilone ograniczenia wynikające z ciężkiej niepełnosprawności), utratę partnera czy też poczucie niespełniania oczekiwań małżonka i nienależytego manifestowania pozytywnych uczuć, zachowań wpisujących się w rolę małżeńską. Widoczne jest także znaczące nasilenie stylu unikowego odzwierciedlającego skłonność badanych do wycofywania się badanych z bliskiej relacji z niepełnosprawnym małżonkiem. Wskazuje to na przeżywanie przez nich uczuć raczej negatywnych w związku z sygnalizowanymi przez małżonka oczekiwaniami umacniania relacji małżeńskiej, większej otwartości na intymny dialog i zwierzanie się.

Przeprowadzona analiza korelacji dowodzi istotnego związku między uwzględnionymi wymiarami satysfakcji małżeńskiej a stylami przywiązania u badanych (tab. 3). Styl bezpieczny pozytywnie koreluje z ogólnym wynikiem zadowolenia 
małżeńskiego, a także z jego wymiarami w postaci intymności i podobieństwa, negatywnie zaś z rozczarowaniem. Przywiązanie lękowo-ambiwalentne oraz unikowe wykazuje dodatni związek z rozczarowaniem oraz ujemny z ogólnie rozumianą satysfakcją małżeńską.

Tabela 3. Style przywiązaniowe a satysfakcja małżeńska u współmałżonków osób z niepełnosprawnością - współczynniki korelacji r Pearsona

\begin{tabular}{lccc}
\hline & Bezpieczny & Lękowo-ambiwalentny & Unikowy \\
\hline Intymność & $0,38^{* * *}$ & 0,14 & 0,05 \\
Rozczarowanie & $-0,36^{* * *}$ & $0,50^{* * *}$ & $0,60^{* * *}$ \\
Samorealizacja & $0,23^{*}$ & 0,11 & 0,01 \\
Podobieństwo & $0,45^{* * *}$ & 0,02 & $-0,11$ \\
Wynik ogólny & $0,23^{*}$ & $-0,46^{* * *}$ & $-0,39^{* * *}$ \\
\hline
\end{tabular}

${ }^{*} \mathrm{p}<0,05 ; * * * \mathrm{p}<0,001$

W dalszej części analiz korelacyjnych sprawdzono, czy siła i charakter związków między wymiarami satysfakcji małżeńskiej a stylami przywiązaniowymi różnicowane są przez zmienne związane z niepełnosprawnością współmałżonka. Uzyskane rezultaty wskazują, iż różnicującą rolę pełni zarówno przyczyna niepełnosprawności (tab. 4), jak i jej percepcja przez pełnosprawnego małżonka (tab. 5).

Przy uwzględnieniu zmiennej w postaci przyczyny niepełnosprawności okazało się, iż nie występuje istotne statystycznie powiązanie między satysfakcją małżeńską a bezpiecznym przywiązaniem u badanych, których współmałżonek choruje na SM. $\mathrm{Z}$ kolei u współmałżonków osób po udarze mózgu nie ustalono istotnego związku między rozczarowaniem a bezpiecznym stylem przywiązania. Zróżnicowaną strukturę powiązań otrzymano również w przypadku stylu lękowo-ambiwalentnego. Niejednoznaczność związków widoczna jest szczególnie w relacji tego typu przywiązania z intymnością. Ujemna korelacja zaznacza się wśród małżonków osób z urazem rdzenia kręgowego, ale dodatnia w przypadku badanych mających małżonka z SM. Istotnego związku między tymi zmiennymi nie odnotowano wśród małżonków osób po udarze mózgu. Charakterystyczne jest, iż wśród małżonków osób z SM nie zaznaczył się związek między rozczarowaniem a przywiązaniem lękowo-ambiwalentnym, określony jako silny i dodatni u pozostałych grup badanych. Okazało się również, iż podobieństwo $\mathrm{w}$ wyznaczaniu celów $\mathrm{i}$ ich realizacji nie ma związku $\mathrm{z}$ analizowanym tu typem przywiązania u małżonków osób po udarze mózgu. A w przypadku pozostałych grup osób badanych związek ten jest niejednolity, zarówno o charakterze dodatnim (SM), jak i ujemnym (UR). Interesujące rezultaty uzyskano także w ramach stylu unikowego. Wśród małżonków osób z SM istotny (ujemny) związek ujawniono 
jedynie w odniesieniu do ogólnego wyniku satysfakcji małżeńskiej. Na uwagę zasługują negatywne korelacje między pozytywnymi wymiarami satysfakcji małżeńskiej (intymność, podobieństwo) a stylem unikowym jedynie u badanych pozostających w małżeństwie z osobą po urazie rdzenia kręgowego. Ponadto bardzo silne dodatnie związki stwierdzono między rozczarowaniem a przywiązaniem unikowym w tej grupie badanych, a także wśród małżonków osób po udarze mózgu.

Tabela 4. Style przywiązaniowe a satysfakcja małżeńska: współczynniki korelacji w grupach badanych zróżnicowanych ze względu na przyczynę niepełnosprawności

\begin{tabular}{lccccccccc}
\hline & $\begin{array}{l}\text { UR } \\
\text { Bezpieczny }\end{array}$ & $\begin{array}{c}\text { SM } \\
\text { UM }\end{array}$ & \multicolumn{2}{c}{$\begin{array}{c}\text { UR } \\
\text { Lękowo-ambiwalentny }\end{array}$} & $\begin{array}{c}\text { SM } \\
\text { UM }\end{array}$ & $\begin{array}{c}\text { UR } \\
\text { Unikowy }\end{array}$ \\
\hline $\mathbf{I}$ & $0,52^{* *}$ & 0,35 & $0,82^{* * *}$ & $-0,50^{* *}$ & $0,40^{*}$ & 0,24 & $-0,53^{* *}$ & 0,31 & 0,12 \\
$\mathbf{R}$ & $-0,78^{* * *}$ & 0,02 & $-0,15$ & $0,68^{* * *}$ & 0,25 & $0,76^{* * *}$ & $0,74 * * *$ & 0,29 & $0,93 * * *$ \\
$\mathbf{S}$ & $0,45^{*}$ & $-0,21$ & $0,59 *$ & $-0,32$ & 0,29 & 0,35 & $-0,26$ & 0,23 & 0,10 \\
$\mathbf{P}$ & $0,56^{* * *}$ & 0,28 & $0,81^{* * *}$ & $-0,53^{* *}$ & $0,38^{*}$ & $-0,05$ & $-0,58^{* * *}$ & 0,30 & $-0,27$ \\
SM-WO & 0,18 & 0,24 & $0,72^{* *}$ & $-0,17$ & $-0,59 * * *$ & $-0,72^{* *}$ & $-0,14$ & $-0,51^{* *}$ & $-0,63 * *$ \\
\hline
\end{tabular}

I - intymność; R - rozczarowanie; S-samorealizacja; P- podobieństwo; SM-WO - wynik ogólny; UR- uraz rdzenia kręgowego; SM - stwardnienie rozsiane UM- udar mózgu $* \mathrm{p}<0,05 ; * * \mathrm{p}<0,01 ; * * \mathrm{p}<0,001$

Tabela 5. Style przywiązaniowe a satysfakcja małżeńska: współczynniki korelacji w grupach badanych zróżnicowanych ze względu na percepcję niepełnosprawności przez pełnosprawnego małżonka

\begin{tabular}{|c|c|c|c|c|c|c|c|c|c|}
\hline & ST & $\mathbf{Z}$ & $\mathbf{W}$ & ST & $\mathbf{Z}$ & $\mathbf{W}$ & ST & $\mathbf{Z}$ & $\mathbf{W}$ \\
\hline & \multicolumn{3}{|c|}{ Bezpieczny } & \multicolumn{3}{|c|}{ Lękowo-ambiwalentny } & \multicolumn{3}{|c|}{ Unikowy } \\
\hline I & 0,12 & 0,27 & $0,38^{*}$ & 0,19 & $-0,16$ & $0,44 * *$ & 0,13 & $-0,16$ & 0,23 \\
\hline $\mathbf{R}$ & $-0,26$ & $-0,13$ & $-0,33^{*}$ & $0,45^{*}$ & $0,41^{*}$ & $0,49 * *$ & $0,58 * *$ & $0,32 *$ & $0,59 * * *$ \\
\hline $\mathbf{S}$ & $-0,02$ & $0,66^{* * *}$ & 0,24 & 0,33 & $-0,29$ & 0,11 & 0,22 & $-0,39 *$ & $-0,17$ \\
\hline $\mathbf{P}$ & 0,12 & $0,45^{* *}$ & $0,56^{* * *}$ & 0,03 & 0,10 & 0,28 & $-0,02$ & $-0,21$ & 0,09 \\
\hline SM-WO & $-0,05$ & $0,42 *$ & $0,34 *$ & $-0,49 *$ & 0,04 & $-0,66 * * *$ & $-0,48 *$ & $-0,14$ & $-0,44 * *$ \\
\hline
\end{tabular}

I - intymność; R - rozczarowanie; S-samorealizacja; P- podobieństwo; SM-WO - wynik ogólny; ST - strata; Z-zagrożenie; W-wyzwanie ${ }^{*} \mathrm{p}<0,05 ; * * \mathrm{p}<0,01 ; * * \mathrm{p}<0,001$

Na podstawie przeprowadzonej analizy korelacji stwierdza się, że związki między wymiarami satysfakcji małżeńskiej a stylami przywiązaniowymi są różnicowane również percepcją niepełnosprawności przez pełnosprawnego małżonka. Przy czym już na wstępie należy podkreślić, iż zmienna ta w nieco mniejszym 
stopniu, w porównaniu do przyczyny niepełnosprawności, ma znaczenie dla ustalania siły i kierunku analizowanych związków (ustalono mniejszą liczbę istotnych statystycznie współczynników korelacji). W przypadku bezpiecznego przywiązania nie stwierdzono jego znaczącego powiązania z satysfakcją małżeńską wśród badanych oceniających niepełnosprawność małżonka w kategorii straty. Istotne związki między tymi zmiennymi ustalono natomiast wśród respondentów postrzegających niepełnosprawność małżonka jako zagrożenie oraz wyzwanie. Co interesujące, przy ocenie $\mathrm{w}$ formie zagrożenia bezpieczne przywiązanie pozytywnie koreluje z ogólnym rozumieniem satysfakcji małżeńskiej, ale także z jej wymiarami w postaci samorealizacji i podobieństwa. Natomiast $\mathrm{u}$ badanych postrzegających wyzwanie w ograniczeniach współmałżonka, bezpieczny styl relacji dodatnio związany jest również z podobieństwem, ale i z intymnością. Związki korelacyjne między stylem lękowo-ambiwalentnym a wymiarami satysfakcji małżeńskiej u badanych z oceną niepełnosprawności w formie straty i zagrożenia są zbliżone. Wyrażają się w pozytywnym powiązaniu tego stylu z rozczarowaniem. Podobną korelację ustalono wśród badanych oceniających niepełnosprawność jako wyzwanie, jednakże w tej grupie badanych zwraca również uwagę dodatni związek przywiązania lękowo-ambiwalentnego z intymnością. W przypadku stylu unikowego, niezależnie od tego, jak badani postrzegają niepełnosprawność współmałżonka, wiąże się on pozytywnie $\mathrm{z}$ rozczarowaniem. Wśród małżonków z oceną w formie zagrożenia zaznaczyła się negatywna korelacja między tego typu przywiązaniem a samorealizacją.

Podsumowującym etapem analiz zmierzających w kierunku ustalenia udziału stylów przywiązaniowych w wyjaśnianiu zmienności poszczególnych wymiarów satysfakcji małżeńskiej badanych współmałżonków osób z niepełnosprawnością ruchową jest prezentacja rezultatów krokowej analizy regresji (tab. 6).

Tabela 6. Rezultaty krokowej analizy regresji

\begin{tabular}{|c|c|c|c|c|c|}
\hline \multirow{4}{*}{$\begin{array}{l}\text { Predyktor } \\
\text { Styl bezpieczny }\end{array}$} & \multirow{2}{*}{\multicolumn{5}{|c|}{$\begin{array}{l}\text { Wskaźnik zmiennej zależnej: Intymnośćc } \\
\mathrm{R}=0,43 ; \mathrm{R}^{2}=0,18 ; \mathrm{cR}^{2}=0,15 \mathrm{~F}(3,81)=6,12 \mathrm{p}<0,001\end{array}$}} \\
\hline & & & & & \\
\hline & $B$ & Btad st. $B$ & $\beta$ & $t(81)$ & $p$ \\
\hline & 0,19 & 0,05 & 0,43 & 3,85 & 0,000 \\
\hline \multirow[t]{2}{*}{ Predyktor } & \multicolumn{5}{|c|}{$\begin{array}{l}\text { Wskaźnik zmiennej zależnej: Rozczarowanie } \\
\mathrm{R}=0,62 ; \mathrm{R}^{2}=0,39 ; \mathrm{cR}^{2}=0,37 \mathrm{~F}(3,81)=17,31 \mathrm{p}<0,001\end{array}$} \\
\hline & $B$ & Btad st. B & $\beta$ & $t(81)$ & $p$ \\
\hline \multirow[t]{2}{*}{ Styl unikowy } & 0,30 & 0,11 & 0,51 & 2,77 & 0,007 \\
\hline & \multicolumn{5}{|c|}{$\begin{array}{l}\text { Wskaźnik zmiennej zależnej: Samorealizacja } \\
\mathrm{R}=0,28 ; \mathrm{R}^{2}=0,08 ; \mathrm{cR}^{2}=0,05 \mathrm{~F}(3,80)=2,36 \mathrm{p}<0,077\end{array}$} \\
\hline
\end{tabular}




\begin{tabular}{|c|c|c|c|c|c|}
\hline \multirow[t]{2}{*}{ Predyktor } & \multicolumn{5}{|c|}{$\begin{array}{l}\text { Wskaźnik zmiennej zależnej: Podobieństwo } \\
\mathrm{R}=0,47 ; \mathrm{R}^{2}=0,22 ; \mathrm{cR}^{2}=0,19 \mathrm{~F}(3,81)=7,59 \mathrm{p}<0,001\end{array}$} \\
\hline & $B$ & Btąd st. B & $\beta$ & $t(81)$ & $p$ \\
\hline Styl bezpieczny & 0,16 & 0,04 & 0,43 & 4,01 & 0,000 \\
\hline \multirow[t]{2}{*}{ Predyktor } & \multicolumn{5}{|c|}{$\begin{array}{l}\text { Wskaźnik zmiennej zależnej: Wynik ogólny } \\
\mathrm{R}=0,57 ; \mathrm{R}^{2}=0,33 ; \mathrm{cR}^{2}=0,30 \mathrm{~F}(3,80)=12,91 \mathrm{p}<0,001\end{array}$} \\
\hline & $B$ & Btąd st. $B$ & $\beta$ & $t(80)$ & $P$ \\
\hline Styl bezpieczny & 0,34 & 0,09 & 0,38 & 3.71 & 0,000 \\
\hline
\end{tabular}

Otrzymane wyniki wskazują na istotne znaczenie bezpiecznego przywiązania dla wyjaśniania nasilenia generalnie rozumianej satysfakcji małżeńskiej oraz jej pozytywnych wymiarów. Stwierdza się, iż bezpieczny styl przywiązaniowy odpowiada za 33\% zmienności ogólnego zadowolenia z małżeństwa u badanych, w mniejszym stopniu bierze udział w wyjaśnianiu poziomu satysfakcji małżeńskiej na płaszczyźnie podobieństwa (22\% wariancji) i intymności (18\% wariancji). Istotne do podkreślenia jest, iż wymiar satysfakcji małżeńskiej w postaci samorealizacji nie podlega tłumaczeniu poprzez charakterystyczne dla badanych style przywiązaniowe. Natomiast zadowolenie małżeńskie rozpatrywane w ramach wskaźnika Rozczarowanie w największym zakresie (w porównaniu z pozostałymi wyznacznikami) wyjaśniane jest przy udziale przywiązania. Wyższe rozczarowanie małżeństwem u badanych można przewidywać na podstawie nasilonego u nich unikowego stylu przywiązaniowego. Przeprowadzona analiza regresji pokazała, iż styl lękowo-ambiwalentny nie ma znaczenia dla objaśniania zjawiska satysfakcji małżeńskiej wśród współmałżonków osób z niepełnosprawnością ruchową.

\section{Zakończenie}

Zaprezentowane analizy podporządkowane były realizacji postawionego celu wyrażającego się w określeniu związku między przywiązaniem a satysfakcją małżeńską u małżonków osoby z niepełnosprawnością ruchową. Uzyskane rezultaty potwierdziły występowanie tego powiązania, ukazując także charakterystyczne właściwości w strukturze uwzględnionych zmiennych. Podsumowując dokonaną prezentację wyników stwierdza się stosunkowo niską satysfakcję małżeńską współmałżonków osób z niepełnosprawnością ruchową. Obniżone parametry wskaźników pozytywnych (przy sygnalnych wynikach wysokich) i nasilone rozczarowanie nakreśla niekorzystny obraz jakości życia małżeńskiego wśród badanych. Ustalone 
tu rezultaty znajdują potwierdzenie w literaturze przedmiotu ${ }^{37}$, jednak, jak wcześniej pisano, subiektywny obraz związku osób pełno- i niepełnosprawnych fizycznie nie zawsze jest niekorzystny, o czym decyduje wiele czynników. W przypadku badań własnych zmiennymi specyfikującymi tendencję może być płeć, z wyraźną przewagą mężczyzn, oraz wiek badanych, z możliwym dla niego kryzysem zaznaczającym się w różnych rolach, w tym partnerskiej.

Style przywiązaniowe nie tworzą klarownej struktury. Po pierwsze, znaczące nasilenie przywiązania negatywnego (unikowego, lękowo-ambiwalentnego) koresponduje z wyraźnym zaznaczeniem przywiązania bezpiecznego. Po drugie, przywiązanie bezpieczne ma niejednolite natężenie wśród badanych. Uzyskane wyniki sugerują zatem skomplikowaną naturę przywiązania u współmałżonków osób z niepełnosprawnością ruchową. Dotychczasowe badania prowadzone w różnych krajach z udziałem osób pełnosprawnych wskazują na stosunkowo najczęstsze rozpowszechnienie stylu bezpiecznego (ok. 50\%), przy rzadziej zaznaczającym się unikowym i lękowo-ambiwalentnym ${ }^{38}$. W kolejnych eksploracjach problematyki warto byłoby przeanalizować czynniki, które wyjaśniają zestawienie stylów przywiązaniowych w kontekście niepełnosprawności małżonka. Przy względnej stabilności indywidualnych różnic w przywiązaniu, możliwe jest wystąpienie zmian związanych z doświadczeniami zyskiwanymi w życiu dorosłym. Efektem tych doświadczeń jest zmiana wewnętrznych modeli reprezentacji siebie i innych ${ }^{39}$.

Otrzymane rezultaty dowodzą, że style przywiązaniowe wykazują istotny związek z satysfakcją małżeńską współmałżonków osób z niepełnosprawnością ruchową. Potwierdzają więc wysuniętą w tym zakresie hipotezę. Należy przy tym podkreślić brak znaczącego udziału stylu lękowo-ambiwalentnego w wyjaśnianiu satysfakcji małżeńskiej w tej grupie osób. Wyniki analizy regresji sugerują również, że styl przywiązania może tłumaczyć w większym stopniu negatywny niż pozytywny wymiar satysfakcji małżeńskiej u współmałżonków osób z niepełnosprawnością. Stosunkowo niewielki procent wyjaśnianej wariancji poszczególnych wymiarów satysfakcji małżeńskiej wskazuje predykcyjną rolę jeszcze innych czynników, mających zapewne większe znaczenie dla jakości relacji rozpatrywanej z perspektywy niepełnosprawności małżonka. Rezultaty dotychczasowych

37 W. van Lankveld, G. Ruiterkamp, G. Näring, D. J. de Rooij, Marital..., dz. cyt., s. 406; E. J. O’Connor, M. P. McCabe, L. Firth, The impact..., dz. cyt., s. 128.

38 C. Hazan, P. Shaver, Romantic love..., dz. cyt., s. 514; C. Hazan, P. Shaver, Attachment..., dz. cyt., s. 16; J. A. Feeney, Attachment..., dz. cyt., s. 51.

39 Za C. Hazan, P. Shaver, Romantic love..., dz. cyt., s. 522; C. Hazan, P. Shaver, Attachment..., dz. cyt., s. 16; B. Paley, M. J.Cox, M. R. Burchinal, C. C. Payne, Attachment and marital..., dz. cyt., s. 592. 
badań z udziałem osób pełnosprawnych w różnych kategoriach wiekowych oraz zróżnicowanych formach związków (narzeczeńskich, małżeńskich, kohabitacyjnych) wskazały na niskie bądź umiarkowane korelacje stylów przywiązania z określonymi wskaźnikami opisującymi jakość relacji, zróżnicowane pod względem kierunku. Styl bezpieczny, podobnie jak w przypadku badań własnych, korelował dodatnio ze wskaźnikami pozytywnymi, jak intymność, namiętność, zaangażowanie, udzielanie wsparcia czy satysfakcja, ujemnie ze wskaźnikami niekorzystnymi dla związku, jak zachowania w kłótni, deprecjacja. Przeciwne wzory powiązań odnotowano w zakresie stylów lękowo-ambiwalentnego oraz unikowego ${ }^{40}$. M. Plopa ${ }^{41}$ wykazał, że wskaźniki małżeńskiej satysfakcji korelują istotnie jedynie ze stylem lękowo-ambiwalentnym, przy czym korzystne dla relacji tworzą związki ujemne, natomiast niekorzystne dodatnie. Należy jednak zauważyć, że podobnie jak w badaniach własnych, wskazywano na brak powiązania w zakresie stylu lękowo-ambiwalentnego ${ }^{42}$.

Na złożony charakter tego typu relacji małżeńskiej wskazuje chociażby pośredniczący udział czynników związanych z niepełnosprawnością. Zarówno przyczyna niepełnosprawności małżonka, jak również jej percepcja przez pełnosprawnego współmałżonka różnicuje siłę i kierunek związku między przywiązaniem a satysfakcją małżeńską. Potwierdzono tym samym sformułowaną hipotezę. W przywoływanym kontekście uwagę zwraca grupa współmałżonków osób ze stwardnieniem rozsianym, u których zakres powiązania między stylami przywiązaniowymi a wymiarami satysfakcji małżeńskiej jest wyraźnie mniejszy. Wiąże się to przypuszczalnie ze specyfiką sytuacji chorobowej, w mniejszym stopniu kontrolowalnej, niż w przypadku np. urazu rdzenia kręgowego, nieprzewidywalnością zakresu i stopnia obciążenia opieką itp. ${ }^{43}$. Stwierdzona w tych badaniach wyróżniająca się rola postrzegania niepełnosprawności małżonka w kategorii zagrożenia, niejednoznaczna w swym oddziaływaniu na relację między przy-

40 C. G. Shields, L. A.Travis, S. L. Rousseau, Marital attachment..., dz. cyt., s. 230; J. A. Feeney, Attachment..., dz. cyt., s. 41; S. A. Meyers, S. A. Landsberger, Direct and indirect..., dz. cyt., s. 167; O. Özmen, G. Atik, Attachment styles... dz. cyt., s. 370; H. Liberska, D. Suwalska, Styl przywiazania..., dz. cyt., s. 29-30; W. Juroszek, O. Haberla, W. Kubeczko, Zależności między stylami przywiązania a intymnościa, namiętnością i zaangażowaniem u narzeczonych, „Kwartalnik Naukowy”, 2012, t. 2 (10), s. 93-95.

41 M. Plopa, Więzi w matżeństwie..., dz. cyt., 2007, s. 299.

42 S. A. Meyers, S. A. Landsberger, Direct and indirect..., dz. cyt., s. 168; W. Juroszek, O. Haberla, W. Kubeczko, Zależności..., dz. cyt., s. 93-95.

43 S. Esmail, B. Munro, N. Gibson, Couple's experience with multiple sclerosis In the context of their sexual relationship, „Sexuality and Disability” 2007, t. 25, s. 166. 
wiązaniem i satysfakcją małżeńską, jest spójna z dotychczasowymi ustaleniami badaczy. Okazuje się bowiem, że szczególnie ten sposób percepcji w największym stopniu (w porównaniu z oceną straty i wyzwania) różnicuje proces przystosowania współmałżonków osób z niepełnosprawnością ruchową ${ }^{44}$.

Zaprezentowane wyniki badań nakreślają złożony i jednocześnie interesujący obszar eksploracji badawczej. Stanowią wstępne rozpoznanie zjawisk przywiązania i satysfakcji małżeńskiej (a także powiązań między nimi) w relacjach kształtowanych obecnością niepełnosprawności. Uzasadniają jednocześnie potrzebę dalszego i bardziej zaawansowanego ich wyjaśniania, jak dotąd sporadycznie podejmowanego na gruncie polskim. Szczególnie przydatne, z perspektywy dotychczasowych ustaleń innych badaczy ${ }^{45}$, byłyby analizy uwzględniające style przywiązania obojga małżonków. Spójność bądź rozbieżność stylów partnerów, a przy tym ich płeć, może mieć znaczenie różnicujące poziom satysfakcji ze związku.

\section{Literatura}

Ackroyd K., Fortune D. G., Price S., Howell S., Sharrack B., Isaac C. L., Adversarial growth in patients with multiple sclerosis and their partners: relationships with illness perceptions, disability and distress, ,Journal of Clinical Psychology in Medical Settings" 2011, t. 18, s. 376.

Banse R., Adult attachment and marital satisfaction: Evidence for dyadic configuration effects, ,Journal of Social and Personal Relationships” 2004, t. 21 (2), s. 280. Bermas B. L., Tucker J. S., Winkelman D. K., Katz J. N., Marital satisfaction in couples with rheumatoid arthritis, „Arthritis Care Research” 2000, t. 13 (3), s. $150-155$.

Blane L., Carmagnani M. I., Ferreira L. M., Health-related quality of life of primary caregivers of persons with paraplegia, „Spinal Cord” 2007, t. 45 (6), s. 401.

Bowlby J., Przywiazanie, Warszawa 2007.

Byra S., Przystosowanie do życia z niepetnosprawnościq ruchowa i choroba przewlekta. Struktura i uwarunkowania, Lublin 2012.

Chandler M., Kennedy P., Sandhu N., The association between threat appraisals and psychological adjustment in partners of people with spinal cord injuries, „Rehabilitation Psychology” 2007, t. 52(4), s. 474-475.

44 M. Chandler, P. Kennedy, N. Sandhu, The association between threat appraisals..., dz. cyt., s. 474.

45 L. A. Kirkpatrick, K. E. Davis, Attachment style..., dz. cyt., s. 510; C. G. Shields, L. A.Travis, S. L. Rousseau, Marital attachment..., dz. cyt., s. 230. 
Dickson A., O'Brien G., Ward R., Allan D., O'Carroll R., The impact of assuming the primary caregiver role following traumatic spinal cord injury: An interpretative phenomenological analysis of the spouse's experience, „Psychology and Health" 2010, t. 25(10), s. 1116.

E. J. O'Connor, M. P. McCabe, L. Firth, The impact of neurological illness on marital relationships, ,Journal of Sex and Marriage Therapy” 2008, t. 24, s. 128.

Esmail S., Munro B., Gibson N., Couple's experience with multiple sclerosis In the context of their sexual relationship, „Sexuality and Disability” 2007, t. 25, s. 166.

Feeney J. A., Attachment, marital interaction, and relationship satisfaction: A diary study, „Personal Relationships” 2002, t. 9, s. 40 i n.

Hazan C., P. Shaver, Romantic love conceptualized as an attachment process, „Journal of Personality and Social Psychology” 1987, t. 52 (3), s. 514 i n.

Hazan C., Shaver P., Attachment as an organizational framework for research on close relationships, „Psychological Inquiry” 1994, t. 5 (1), s. 8.

Heszen-Niejodek I., Problemy chorych somatycznie, w: Psychologia. Podręcznik akademicki, red. J. Strelau, t. 3, Gdańsk 2005, s. 514.

Jarnecke A. M., South S. C., Attachment orientations as mediators in the intergenerational transmission of marital satisfaction, ,Journal of Family Psychology” 2013, t. 27 (4), s. 556.

Jaworski T. M., Richards J. S., Lloyd L. K., Retrospective review of sexual and marital satisfaction of spinal cord of spinal cord injury and diabetic males post penile injection or implant, „Urology” 1992, t. 40 (2), s. 127-131.

Juroszek W., Haberla O., Kubeczko W., Zależności między stylami przywiazania a intymnością, namiętnościa i zaangażowaniem u narzeczonych, „Kwartalnik Naukowy", 2012, t. 2 (10), s. 93-95.

Kaźmierczak M., Błażek M., Attachment styles as predictors of the perception of couples' cohesion, „Social Behavior and Personality” 2015, t. 43 (6), s. 1056.

Kirkpatrick L. A., Davis K. E., Attachment style, gender, and relationship stability: a longitudinal analysis, ,Journal of Personality and Social Psychology” 1994, t. 66 (3), s. 509.

Kobak R. R., Hazan C., Attachment in marriage: effects of security and accuracy of working models, „Journal of Personality and Social Psychology” 1991, t. 60 (6), s. 862 i n.

Lankveld (van) W., Ruiterkamp G., Näring G., de Rooij D. J., Marital and sexual satisfaction in patients with RA and their spouses. „Scandinavian Journal of Rheumatology" 2004, t. 33, s. 406.

Liberska H., Suwalska D., Styl przywiazania a relacje partnerskie we wczesnej dorostości, „Psychologia Rozwojowa” 2011, t. 16 (1), s. 26. 
Marchwicki P., Style przywiqzania a postawy rodzicielskie. Doniesienie z badań, „Roczniki Psychologiczne” 2004, t. VII (2), s. 83.

McPherson Ch. J., Wilson K. G., Chyurlia L., Leclerc Ch., The caregiving relationship and quality of life among partners of stroke survivors: A cross- sectional study, „Health and Quality of Life Outcomes” 2011, t. 9, s. 29.

Meyers S. A., Landsberger S. A., Direct and indirect pathways between adult attachment style and marital satisfaction, „Personal Relationships” 2002, t. 9, s. $160 \mathrm{i} \mathrm{n.}$

O’Connor E. J., McCabe M. P., Predictors of quality of life in carers for people with a progressive neurological illness: a longitudinal study, „Quality Life Research" 2011, t. 20, s. 707.

Ottu F. A., Akpan U. I., Predicting marital satisfaction from the attachment styles and gender of a culturally and religiously homogenous population, „Gender and Behaviour" 2011, t. 9(1), s. 3669.

Özmen O., Atik G., Attachment styles and marital adjustment of Turkish married individuals, „Procedia Social and Behavioral Sciences” 2010, t. 5, s. 370.

Paley B., Cox M. J., Burchinal M. R., Payne C. C., Attachment and marital functioning: comparison of spouses with continuous-secure, earned-secure, dismissing, and preoccupied attachment stances, ,Journal of Family Psychology” 1999, Vo. 13 (4), s. 591.

Palus K., Wybrane psychologiczne uwarunkowania braku partnera życiowego w okresie wczesnej dorostości, Poznań 2010.

Plopa M., Więzi w matżeństwie i rodzinie. Metody badań, Kraków 2007.

Redeleman M. J., Sexual difficulties for persons with multiple sclerosis in New South Wales, Australia, "International Journal of Rehabilitation Research" 2009, t. 32 (4), s. 337-347.

Rogers W. S., Bidwell J., Wilson L., Perception of and satisfaction with relationship power, sex, and attachment styles: a couples level analysis, „Journal of Family Violence" 2005, t. 20 (4), s. 248.

Rostowski J., Rostowska T., Malżeństwo i mitość. Kontekst psychologiczny i neuropsychologiczny, Warszawa 2014.

Shields C. G., Travis L. A., Rousseau S. L., Marital attachment and adjustment in older couples coping with cancer, „Aging and Mental Health” 2000, t. 4 (3), s. 230.

Weitzenkamp D. A., Gerhart K. A., Charlifue S. W., Whiteneck G. G., Savic G., Spouses of spinal cord injury survivors: the added impact of caregiving, „Archives of Physical Medicine and Rehabilitation” 1997, t. 78 (8), s. 824. 
Ybema J. F., Kuijer R. G., Hagedoorn M., Buunk B. P., Caregiver burnout among intimate partners of patients with a severe illness: An equity perspective, „Personal Relationships” 2002, t. 9 (1), s. 79-81.

Yim S. Y., Lee I. Y., Yoon S. H., Song M. S., Rah E. W., Moon H.W., Quality of marital life in Korean spinal cord injured patients, „Spinal Cord” 1998, t. 36, s. 828-829.

\section{Stanisława Byra, Monika Parchomiuk: Attachment and marital satisfaction among spouses of individuals with a mobility disability}

The paper presents the results of author's own research investigating the relationships between attachment styles and marital satisfaction among partners of individuals with a mobility disability. The analyses were intended to determine the strength of attachment behaviours (secure, avoidant and ambivalent [anxious-resistant insecure] attachment) and to identify the general level of relationship satisfaction and its specific aspects (intimacy, dissapointment, self-fulfilment and similarity), as well as the correlation between the two variables. Also, the significance of variables such as the cause of spouse's disability and manner in which the disability has been perceived by the non-disabled spouse for the correlation was also verified. The research material was obtained from 85 spouses of individuals who became disabled as a result of a spinal cord injury, multiple sclerosis, stroke and lower limb amputation. Measures used in the study included the Well-Matched Marriage Questionnaire (KDM-2) developed by M. Plopa and J. Rostowski; Attachment Style Questionnaire (KSP) by M. Plopa; Permanent Disability/Chronic Disease and Accompanying Limitations Questionnaire by S. Byra, as well as author's own questionnaire.

Key words: attachment style, martial satisfaction, marriage, physical disability. 